\title{
Mountain Farmers' Perception of on-farm Environmental Degradation, the Case of Damota, Southern Ethiopia
}

\author{
Getahun Garedew Wodaje \\ Department of Environmental Science, Wolaita Sodo University, Wolaita Sodo, Ethiopia \\ Email address: \\ getahungaredew@gmail.com \\ To cite this article: \\ Getahun Garedew Wodaje. Mountain Farmers' Perception of on-farm Environmental Degradation, the Case of Damota, Southern Ethiopia. \\ International Journal of Environmental Protection and Policy. Vol. 8, No. 6, 2020, pp. 123-128. doi: 10.11648/j.ijepp.20200806.13
}

Received: November 24, 2020; Accepted: December 18, 2020; Published: December 25, 2020

\begin{abstract}
Mountain people understand environmental degradation only at times when they lost the production options of their farmlands that sustained them in the past. This study was conducted to assess the farmers' perception of on-farm environmental degradation in mount Damota, Southern Ethiopia. Data collection techniques used in this study was interviews, focus group discussions, field observations and questionnaires. Multi-stage Purposive and Systematic sampling technique methods were used to select study sites and households, respectively. Using systematic sampling technique from all the four kebeles of the Woreda a total of 200 households was selected. Data were presented in descriptive statistics. The result of the study shows that almost all households appreciate the causes, indicators and problems of on-farm environmental degradation. $69 \%$ of the respondents agree that their land is severely eroded while $24.5 \%$ say it is moderate on their land holding. Only $6.5 \%$ say the erosion rate is slight on their land holding and none of the respondents doubt the problem of soil erosion on their agricultural productivity and natural resource base. The main reason of depletion of the natural vegetation as perceived by the respondents is clearance of the forest for farming, over grazing and timber cutting. About the climatic problems of farm lands on the mountain, flood during the rainy season (which is also the growing season) is their main problem and windstorm and drought were also seen by the study population as the main climatic problem of the area.
\end{abstract}

Keywords: Perception of Farmers, Damota Mountain, Environmental Degradation

\section{Introduction}

Different biophysical variables in a given area make up the environment and the interactions of these variables were influenced by socioeconomic factors of the area. Moreover, the biophysical factors generating environment as a joint product are not only contributors to but also products of the environment $[5,10]$.

The process of environmental changes can be presented as a rate and pattern of deforestation, soil erosion, disruption in water movements, reduction in biodiversity, and interdependence of various biophysical variables as a part of regenerative process $[4,6]$. In Ethiopia, natural resources are under the influence of various interrelated factors like population pressure, agricultural expansion, resettlement, climate change, and environmental pollution. Because of its rugged topography and unsustainable land management practices soil degradation is common throughout the country and it decreased land productivity and also increased social problems [7].

Physical attributes (topography, altitude, slope, etc) play an important role in environmental changes [16]. Therefore, when dealing with mountain areas, Specific conditions or characteristics of mountain areas that arise due to the physical attributes need to be considered. The mismatch between mountain conditions and human activities, insensitive to the limitations of the resource base, leads to environmental degradation [5].

People residing in the mountain understand environmental degradation only at times when they lost the production options of their farmlands. These farmers, owning small degraded land, obliged to produce more than ever before due to the increasing number of people without any viable technologies. These lead to negative environmental changes on the lands of mountains $[6,17]$.

The Ethiopian mountains are experiencing serious environmental problems as a result of deforestation, overgrazing, agricultural encroachment and the unregulated 
use of agrochemicals, which in turn caused food shortage and degradation of natural resources. Mountain agriculture was seemingly sustainable till population pressure was low and ultimate goal of agriculture was to achieve local production based food security. But with integration of mountain societies in to the mainstream market, the management goal has been shifting more and more towards profit maximization $[3,13,15]$.

In Mount Damota, as in other mountainous areas, there are strong causal relationships among the state of the environment, human well-being and vulnerability. Environmental assets that can provide important opportunities for improving the human well-being are being over exploited. Natural hazards, such as floods, droughts, and landslides also threaten everyone residing on the mountain. So it is compulsory to see the current land related negative environmental changes with respect to the high level of human interventions. This research was intended to evaluate how local communities' perceive their environment in order to help understand the causes of ecological degradation on Mount Damota and Point out indicators of un-sustainability that face their farming system.

\section{Materials and Methods}

\subsection{Description of the Study Area}

Mount Damota is located in south central Ethiopia between $6.4^{\circ}-6.9^{\circ} \mathrm{N}$ latitude and $37.4^{\circ}-37.8^{\circ} \mathrm{E}$ longitude and is at $390 \mathrm{~km}$ distance from Addis Ababa, the capital city of Ethiopia. The Mountain is found in the Wolaita zone of the Southern Nations Nationalities and Peoples Regional State (SNNPRS), and holds three Woredas of the Zone.

The mean annual temperature of the Damota area varies from $16^{\circ} \mathrm{C}$ to $19.9^{\circ} \mathrm{C}$ and the annual monthly temperature varies throughout the year from $16^{\circ} \mathrm{C}$ to $19.7^{\circ} \mathrm{C}$. The absolute maximum temperature occurs in mid-march and is about $28^{\circ} \mathrm{C}$ and the absolute minimum temperature occurs in November and is about $10.8^{\circ} \mathrm{C}$. The annual mean rainfall from the records in the nearby stations is around $1375 \mathrm{~mm}$. Mount Damota is a part of the most densely populated area in the country and is being cultivated up to the top even on steep slopes [11].

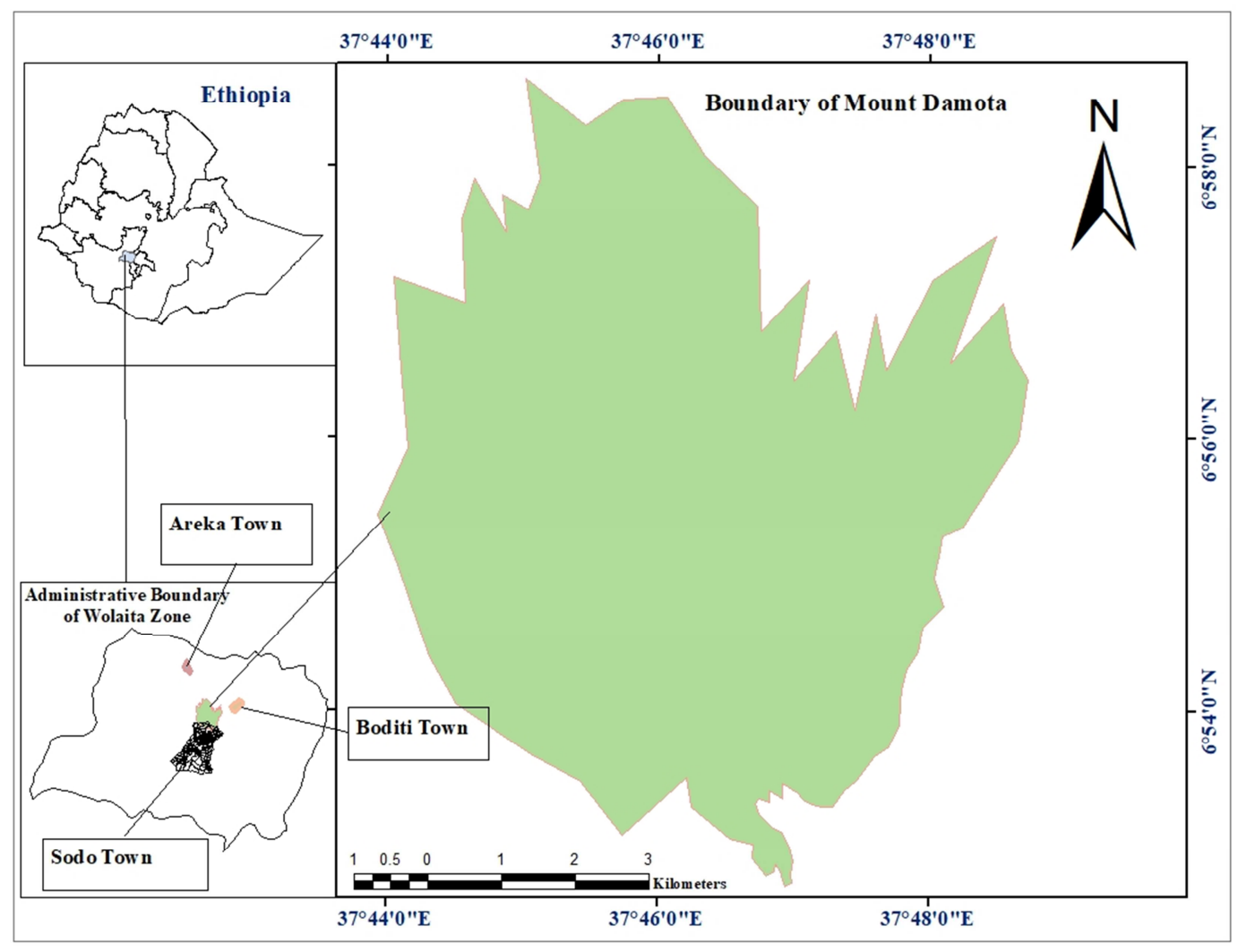

Figure 1. Map of the study area.

\subsection{Data Collection and Sampling Technique}

Multi-stage Purposive and Systematic sampling technique methods were used to select study sites and households, respectively. The first stage was to apply purposive sampling techniques and therefore Damot gale Woreda was selected from the other two Woredas due to its more human encroachment on Damota mountain and because the majority of the kebeles are exposed to degradation problems. In stage two four Kebeles were purposively selected from the Damot Gale Woreda. This is based on their higher population density and human encroachment as well as the degree of disturbance of the natural resources that represent the various topographic features and land use patterns. These are: Akabilo, Woshi Gale, Wondara Gale and Wondara Boloso 
Kebeles. In the third stage a random sampling technique was employed to take representative respondents from the selected kebeles. Thus, the sample size for the study was 200 and the researcher used systematic sampling technique from all the four kebeles of the woreda. Accordingly, from the registry-frame of kebeles, 50 households from each kebele were selected. Considering the homogeneity of the households in their livelihood is more representative to the rest of the population.

\subsection{Methods of Data Analysis}

Descriptive statistical procedure of the statistical package for the social sciences (SPSS version 20) was used in analyzing and summarizing the data obtained through questionnaires survey. The qualitative description was used to describe data acquired through focus group discussions and field observations.

\section{Results and Discussion}

\subsection{Household and Farm Characteristics}

The survey revealed that 100 percent of the households were farm dependent and the household size was between 2 and 17 with a mean of 7.6 members. Across the households, the average land size is 0.54 hectares and only 2.5 percent of the households have land size of more than 1 hectare.

Fifty four percent of the land is owned before 15 years and owing to saturation of fragmentation, the amount of the land owned in the last 5 years (by all means i.e. from family, government, purchased and cleaned forest) is only 9 percent of the total owned land. Young men used to inherit land from their parents when they got married, but this rarely happens now that households have such smallholdings. This resulted in such an extended family size (of 7.6/HH) when compared to a regional average of 4.7 persons per household and a zonal average of 4.9 persons per household.
Agriculture in the study area is mainly subsistent rain-fed crop cultivation practice, with little use of modern agricultural inputs and supplemented with some livestock production. Crop cultivation is carried out on land ranging from gentle to very steep slopes. Although different types of crops are cultivated, the most predominant one are Maize, Barely, Wheat, Bean \& pea, Root crops and Enset. This constitutes the basis of the economy of the Damota area.

Wolaita zone in southern Ethiopia is known for its high population density in the country. Districts of Soddo zuria, Boloso sore and Damot Gale with a population density of 600, 678 and 781 per square kilometer are parts of the zone where Mount Damota lies (Regional bureau of Finance and Economic Development Division of statistics and population, 2007). These already saturated areas are also expected to continue with at least $2.9 \%$ annual population growth rate of the regional average.

Since 2004 the average population growth rate of the study Kebele's were $3.13 \%, 3.0 \%, 2.99 \%$ and $3.01 \%$ for Akabilo, Woshi Gale, Wondara Gale and Wondara boloso respectively [11]. This result shows that, though the study area is located on a highly fragile mountain side, its population continued to grow with rates comparable to that of the nearby plain areas.

\subsection{Farmers' Perception on Agricultural Problems}

Informants told that they face four most significant problems related to agricultural production. Rain fall variability $(71.4 \%)$ and landslide $(18.1 \%)$, decline in soil fertility $(10.1 \% \mathrm{t})$ and the prevalence of weeds; insect pest and disease problem $(0.5 \%)$ were the highest agricultural problems perceived by the farmers in the study area. As understood from the group discussions, agriculture in the study area suffers from erratic rainfall characteristics and its variability especially during the onset of the growing season. Landslide on the marginal farmlands occurring during the rainy seasons is also another threat for them and their cattle's.

Table 1. Major agricultural production and environmental problems Perceived by the farmers.

\begin{tabular}{|c|c|c|c|c|c|c|c|c|c|c|}
\hline \multirow{2}{*}{$\begin{array}{l}\text { Major agriculture production } \\
\text { problems }\end{array}$} & \multicolumn{2}{|l|}{ Akabilo } & \multicolumn{2}{|l|}{ Woshi Gale } & \multicolumn{2}{|c|}{ Wondara boloso } & \multicolumn{2}{|c|}{ Wondara Gale } & \multicolumn{2}{|l|}{ Over all } \\
\hline & Frequency & $\%$ & Frequency & $\%$ & Frequency & $\%$ & Frequency & $\%$ & Frequency & $\%$ \\
\hline Decline of soil fertility & 0 & 0 & 3 & 6 & 11 & 22 & 7 & 14 & 20 & 10.1 \\
\hline Land slide & 1 & 2 & 4 & 8 & 14 & 28.6 & 17 & 34 & 36 & 18.1 \\
\hline Rain fall variability & 49 & 98 & 43 & 86 & 25 & 51 & 25 & 50 & 142 & 71.4 \\
\hline Damage by pest and disease & 0 & 0 & 0 & 0 & 0 & 0 & 1 & 2 & 1 & 0.5 \\
\hline Total & 50 & 100 & 50 & 100 & 50 & 100 & 50 & 100 & 200 & 100 \\
\hline
\end{tabular}

The over exploitation of natural resources without considering their regenerative capacity of a given area raises a question of biodiversity loss in that locality. In interviews during the field survey it is understood that people of the study area are aware of the loss of some native species. The bamboo tree which has been the alternative income source by its production and bamboo craft works in the nearby towns is no more available for these purposes.

Negative changes in environmental parameters like land/topsoil fertility; vegetation, water flows and seasonal stresses; can show the unsustainable condition of a given agroecology [5].

In cultural farming system of Wolaita the homestead fields closer to resident were very fertile while the out fields were less fertile across farms. So, the soil fertility gradient decreases within a farm with distance from the home due to management differences $[9,12]$.

In addition to this problem of non-uniformity, deforestation and the use of crop residues and manure as fuel are causes of soil degradation and accelerated erosion. But 
Cultivation of steep slopes stands above all land related problems of the Mountain. The Damota farmers till the land with ox ploughs, using the local maresha to prepare seedbeds and control weeds. According to traditional wisdom, welltilled soils produce higher yields, so they aim to till several times a year, regardless of slope.

Although, the farmers are using the traditional terracing method and inorganic fertilizers for soil conservation and fertility management of their farmland it is hardly possible for them to produce cereals with a minimum soil lose in such steep slope farmland. The farmers also agree that sooner or later their farm land will be abandoned because of the loss of top soil and un-sustainability of their farming system.

Table 2. How did you see the agricultural production of your Kebele in the last 20 years?

\begin{tabular}{llll}
\hline & & Frequency & Percent \\
\hline \multirow{4}{*}{ Valid } & Reduced & 149 & 74.5 \\
& Increased & 46 & 23.0 \\
& Constant & 3 & 1.5 \\
& Cannot determine & 2 & 1.0 \\
Total & & 200 & 100.0 \\
\hline
\end{tabular}

74 percent of the respondent farmers argued that the agricultural production of their Kebele was reduced in the last 20 years. The 23 percent, who said that the production is increased, also pointed out their mechanism for production increase is agricultural land expansion. Older farmers were repeatedly reported a decline in yields due to deteriorating soil conditions. They complained that they were able to harvest much greater product from their small farm than what could be obtained from a much larger farm today. But this couldn't be substantiated by Comparative yield statistics due to unavailable of such a data.

\subsection{Farmers' Perception of Resource Degradation}

Farmers' perception and attitude towards conservation of natural resources can have major bearing on resource management [2]. To identify the most important agricultural and environmental issues and traditional conservation practices in the study area, households were asked to indicate the current state of natural resources and the extent of the problem. In addition, a group discussion was held with community elders to enrich the data.

Degradation is associated with the destruction of natural forests, overgrazing, hillside demolition, and the increasingly intensive use of land for crops in the absence of conservation measures. In the study area, marginal land is being cultivated in response to the shortage of farmland in the mountains due to increasing population pressure.

The major cause of land degradation in mountain areas is soil erosion which depends both on natural conditions and on land use patterns. Under natural condition the climate (especially rain intensity), slopes, vegetation cover and the nature of the soil are important parameters. With regard to land use the major one human activity, which entails the removal of the protective vegetation cover, is improper measures such as ploughing along slopes [14].

$69 \%$ of the respondents agree that their land is severely eroded while $24.5 \%$ say it is moderate on their land holding. Only $6.5 \%$ say the erosion rate is slight on their land holding and none of the respondents doubt the problem of soil erosion on their agricultural productivity and natural resource base. During the survey some respondents argued that their land is moderately eroded while there is already gully formation on their farmland. This is because they compare their farm with the already abandoned land due to severe erosion on the steep slopes.

Table 3. The current state of soil erosion as perceived by farmers of the Study Area.

\begin{tabular}{|c|c|c|c|c|c|c|c|c|c|c|}
\hline \multirow{2}{*}{$\begin{array}{l}\text { Type of } \\
\text { erosion rate }\end{array}$} & \multicolumn{2}{|c|}{ Akabilo } & \multicolumn{2}{|c|}{ Woshi Gale } & \multicolumn{2}{|c|}{ Wondara boloso } & \multicolumn{2}{|c|}{ Wondara Gale } & \multicolumn{2}{|c|}{ Overall } \\
\hline & Fre. & $\%$ & Fre. & $\%$ & Fre. & $\%$ & Fre. & $\%$ & Fre. & $\%$ \\
\hline Slightly eroded & 0 & 0 & 7 & 14 & 0 & 0 & 6 & 12 & 13 & 6.5 \\
\hline Moderately eroded & 0 & 0 & 29 & 58 & 9 & 18 & 11 & 22 & 49 & 24.5 \\
\hline Severely eroded & 50 & 100 & 14 & 28 & 41 & 82 & 33 & 66 & 138 & 69.0 \\
\hline Total & 50 & 100 & 50 & 100 & 50 & 100 & 50 & 100 & 200 & 100 \\
\hline
\end{tabular}

Under natural conditions vegetation cover protects the soil from direct rainfall and moderates run-off. But when water is channeled across unprotected land and washes away the soil along the drainage lines gully erosion occurs. It is becoming more common to see gully in the foot of mount Damota these days.

There is problem of securing agriculture and livelihood on steep slopes without disturbing the natural vegetation. As most rural livelihoods are dependent on the natural resource base of the mountain at least to some extent Natural resources management in mountain environment becomes a big challenge to the existing human understanding and organizational ability [8].

Almost, all households interviewed acknowledged the presence of dense vegetation cover in their near past memory.
The result shown in the table 4 suggests that $89.5 \%$ of the sample population reported that the forest resource of their locality had already been depleted, while $10.5 \%$ of them felt that the forest resource is depleting. Of the $89.5 \%$ who responded that the forest resource is depleted $63.5 \%$ agree on the severity of the condition.

The main reason of depletion of the Natural vegetation as perceived by the $51.5 \%$ respondents is clearance of the forest (for farming) - while 20.5\% pointed out over grazing followed by timber cutting-19\% and some others (9\%) generally say it is the unfavorable climatic condition which is responsible for the depletion of the natural vegetation of the mountain. About the climatic problems of their kebeles' $85 \%$ informants say, flood (during the rainy season, which is also the growing season) is their main problem. Windstorm and 
Drought were respectively seen by $5.5 \%$ and $9.5 \%$ of the study population as the main climatic problem of the area.

Changes in water flow are difficult to measure unless one uses an experimental mode of investigation. In the present case, however, indicators of decline or instability of water flows were seen in terms of the status of water flow in the water falls of the mountain and small streams having their head water on the mountain. A number of them, unlike in the past, do not flow during part of the year. The reduced water supplies are reflected in drinking water points (usually springs in the valley). The increased frequency of flash floods on the one hand and moisture stress for crops on the other hand indicate the increased instability of the moisture situation.

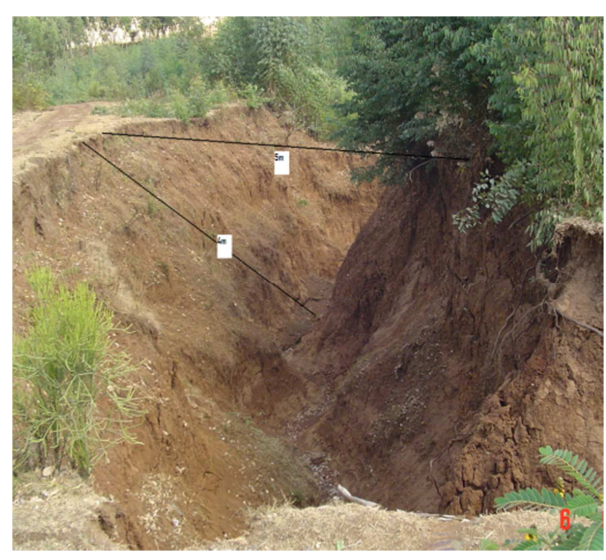

Figure 2. Gully formation on the foot of the mountain.

Table 4. The state of Natural vegetation as perceived by the Study Population.

\begin{tabular}{|c|c|c|c|c|c|c|c|c|c|c|}
\hline \multirow{2}{*}{$\begin{array}{l}\text { Deforestation rate at } \\
\text { present state }\end{array}$} & \multicolumn{2}{|l|}{ Akabilo } & \multicolumn{2}{|l|}{ Woshi Gale } & \multicolumn{2}{|c|}{ Wondara boloso } & \multicolumn{2}{|c|}{ Wondara Gale } & \multicolumn{2}{|l|}{ Over all } \\
\hline & Frequency & $\%$ & Frequency & $\%$ & Frequency & $\%$ & Frequency & $\%$ & Frequency & $\%$ \\
\hline Depleting & 0 & 0 & 20 & 40 & 1 & 2 & 0 & 0 & 21 & 10.5 \\
\hline Depleted & 0 & 0 & 17 & 34 & 22 & 44 & 13 & 26 & 52 & 26.0 \\
\hline Severely depleted & 50 & 100 & 13 & 26 & 27 & 54 & 37 & 74 & 127 & 63.5 \\
\hline Total & 50 & 100 & 50 & 100 & 50 & 100 & 50 & 100 & 200 & 100 \\
\hline
\end{tabular}

\subsection{Farmers' Perception of Plot Location}

$13 \%$ of the farmers of the study area perceived that their land is on steep slope, while $33 \%$ perceived it is on gentle. Hill top and valley bottom is occupied by $23 \%$ and $28 \%$ of the households respectively. Only $3 \%$ of the respondents say that they are farming on table land.

Table 5. Type of plot location, perceived by the farmers of the study Area..

\begin{tabular}{|c|c|c|c|c|c|c|c|c|c|c|}
\hline \multirow{2}{*}{ The type of plot location } & \multicolumn{2}{|l|}{ Akabilo } & \multicolumn{2}{|l|}{ Woshi Gale } & \multicolumn{2}{|c|}{ Wondara boloso } & \multicolumn{2}{|c|}{ Wondara Gale } & \multicolumn{2}{|l|}{ Over all } \\
\hline & Frequency & $\%$ & Frequency & $\%$ & Frequency & $\%$ & Frequency & $\%$ & Frequency & $\%$ \\
\hline On gentle & 45 & 90 & 18 & 36 & 3 & 6 & 0 & 0 & 66 & 33 \\
\hline On steep slope & 0 & 0 & 16 & 32 & 10 & 20 & 39 & 78 & 26 & 13 \\
\hline On Hill top & 0 & 0 & 5 & 10 & 2 & 4 & 11 & 22 & 46 & 23 \\
\hline In valley bottom & 0 & 0 & 10 & 20 & 35 & 70 & 0 & 0 & 56 & 28 \\
\hline On table land & 5 & 10 & 1 & 2 & 0 & 0 & 0 & 0 & 6 & 3 \\
\hline Total & 50 & 100 & 50 & 100 & 50 & 100 & 50 & 100 & 200 & 100 \\
\hline
\end{tabular}

During the field survey it has been seen that farmers of the mountain perceive that their farmland is in gentle just by comparing it with the nearby inaccessible steep slope lands. Most of the farmers residing in mount Damota have never been in gentle lands for agriculture purpose, thus their frame of reference for plot location depended on their poor experience for gentle farmlands. Though standards show slope angle of only $2^{\circ}-5^{\circ}$ categorized under gentle land [1], in the study area farmlands having slope angle of up to $16^{\circ}$ have been perceived as gentle. Land of this steepness is nearly the upper limit for mechanized cultivation. During the field survey, in a particular plot, it has been seen that a land having slope angle of $58^{\circ}$ is cultivated for cereal production but in the standard, land with slope angle of $18^{\circ}-30^{\circ}$ is generally too steep for agriculture.

Indigenous methods of Maintaining soil Fertility

The increase in population pressure has led to the encroachment of crop land on to the steep slopes of the mountain. The imbalance between crop land and forest land, in turn, leads to soil erosion and continued environmental degradation. To combat this problem traditional practices of maintaining soil fertility are being practiced by the study population. In the last four consecutive years different types of soil and water conservation measures initiated by the Damota rehabilitation project of the Zonal government were introduced to the study area. The majority of soil and water conservation measures introduced to the area are mechanical conservation measures supported by plantation of seedling in the summer rainy season. Measures introduced to the study area on farmlands include soil bunds, and fanya juu terraces with very few stone bunds. $77 \%$ of the respondents of the survey use earth terracing to protect their farm land from soil erosion due to flood during any spot of rain. 19\% say they generally use agro-forestry as a method of maintaining soil fertility and $2.5 \%$ and $1.5 \%$ use inter cropping and crop rotation respectively. They were introduced with objectives of conserving, developing and rehabilitating degraded agricultural lands and increasing food security through increased food production.

Financially destitute farmers within the consider zone 
lease their own farm lands for other financially way better ranchers. This in turn influenced the execution of preservation practices negatively.

Table 6. Indigenous practices to maintain soil fertility as practiced by respondents.

\begin{tabular}{lll}
\hline Indigenous practices & Frequency & Percent \\
\hline Earth terraces & 154 & 77 \\
Agro-forestry & 38 & 19 \\
Inter cropping & 5 & 2.5 \\
Crop rotation & 3 & 1.5 \\
Total & 200 & 100 \\
\hline
\end{tabular}

\section{Conclusion}

In this paper an attempt has been made to review the causes of ecological degradation on Mount Damota and Point out indicators of un-sustainability that face their farming system as perceived by local farmers. The results in this study revealed that there are limited alternatives to land use other than farming and cultivation of steep slopes has led to severe soil erosion. From the present finding it is clear that the study area is under serious threat of environmental degradation which is found to be mainly human induced. Increasing human population on top of poor planning forced farmers to use the land more intensively and more frequently. Careful investigation and immediate intervention from all concerned bodies to implement integrated environmental rehabilitation strategies is mandatory. Existing biophysical, socioeconomic, and institutional conditions need amendments based on further study.

\section{References}

[1] Alan, C. and Peter, C. 1987. Process and land forms. Conceptual frameworks in geography. Oliver and Boyed.

[2] Ayana, A., Vandenabeele, N. and Arts, B. 2017. Performance of participatory forest management in Ethiopia: institutional arrangement versus local practices, Critical Policy Studies 11: 1, 19-38, DOI: 10.1080/19460171.2015.1024703.

[3] Birhanu, A., 2014. Environmental Degradation and Management in Ethiopian Highlands: Review of Lessons Learned. International Journal of Environmental Protection and Policy 2 (1): 24.

[4] Ibisch, P. L. \& A. Vega E., T. M. Herrmann (eds.) 2010. Interdependence of biodiversity and development under global change. Technical Series No. 54. Secretariat of the Convention on Biological Diversity, Montreal (second corrected edition).
[5] Jeanne x., Roger E. and Turner, B. L. 1995. Regions at risk: comparison of treated environment. United Nations university press, Tokyo.

[6] Kasperson, J. X., Kasperson, R. E. and Turner, B. L. 1995. Regions at risk: comparisons of threatened environments. New York: United Nations University Press.

[7] Merkineh M M, Aklilu B M, Efrem G, Gashaw G. Community Adoption of Watershed Management Practices at Kindo Didaye District, Southern Ethiopia. Int J Environ Sci Nat Res. 2018; $14 \quad$ (2): 555881. DOI: 10.19080/IJESNR.2018.14.555881.

[8] Sati, V. P. 2004. Resource Utilization Pattern and Development in Hills: A Case for the Pindar Basin of Garhwal Himalaya, India. Journal of Mountain Science, 1 (2). PP. $155 \sim 165$.

[9] Soil Conservation Research Programme (SCRP). 1996. Data base report (1982-1993) Series II: Gununo Research Unit, University of Berne, Berne.).

[10] Sherbinin, A., Carr, D., Cassels, S., and Jiang, L. 2007. Annual Review of Environment and Resources. Population and Environment 32 pp 345-373.

[11] SNNPR Regional Bureau of Finance and economic dev. Division of statistics and population, 2007. socio-economic profile of the SNNPR region.

[12] Tilahun Amede, and Endale Taboge. 2004. Enhancing farmer innovation through manipulation of soil fertility gradients in Enset systems. Paper presented at the African Soils Network (AFNet) Conference (In press). Yaoundé, Cameroon.

[13] Tilahun Amede, Takele Belachew and Endrias Geta. 2001. Reversing Degradation of Arable Lands in Southern Ethiopia. African Highlands Initiative (AHI). Working Papers \# 1.

[14] United nations population information network (POPIN). 1995. Background document on the population programme of the united nations. UN Population Division, Department of Economic and Social Affairs.

[15] Wassie, S. B., 2020. Natural resource degradation tendencies in Ethiopia: a review. Environmental Systems Research 9 (33).

[16] Wondie, M., Teketay, D., Melesse, A. M. and Schneider, W. 2012. Relationship between Topographic Variables and Land Cover in the Simen Mountains National Park, a World Heritage Site in Northern Ethiopia. International Journal of Remote Sensing Vol. 2.

[17] Wymann von Dach S, Romeo R, Vita A, Wurzinger M, Kohler $\mathrm{T}$ (eds). 2013. Mountain Farming Is Family Farming: A contribution from mountain areas to the International Year of Family Farming 2014. Rome, Italy: FAO, CDE, BOKU, pp. 100. 